\title{
Mast Cells in the Auditory Periphery of Rodents
}

\author{
Agnieszka J. Szczepek ${ }^{1, *}{ }^{*}$, Tatyana Dudnik ${ }^{1}$, Betül Karayay ${ }^{1}$, Valentina Sergeeva ${ }^{2}$, \\ Heidi Olze $^{1}$ and Alina Smorodchenko ${ }^{3}$
}

1 Department of Otorhinolaryngology, Head and Neck Surgery, Charité-Universitätsmedizin Berlin, Corporate Member of Freie Universität Berlin, Humboldt-Universität zu Berlin, and Berlin Institute of Health, 10117 Berlin, Germany; tatyana.dudnik@charite.de (T.D.); betuel.karayay@charite.de (B.K.); heidi.olze@charite.de (H.O.)

2 Department of Medical Biology with Course of Microbiology and Virology, Chuvash State University, 428034 Cheboksary, Russia; kafedra-biology@yandex.ru

3 Department of Human Medicine, MSH Medical School Hamburg, University of Applied Sciences and Medical University, 20457 Hamburg, Germany; alina.smorodchenko@medicalschool-hamburg.de

* Correspondence: agnes.szczepek@charite.de; Tel.: +49-30-450-555-224

Received: 1 September 2020; Accepted: 25 September 2020; Published: 1 October 2020

\begin{abstract}
Mast cells (MCs) are densely granulated cells of myeloid origin and are a part of immune and neuroimmune systems. MCs have been detected in the endolymphatic sac of the inner ear and are suggested to regulate allergic hydrops. However, their existence in the cochlea has never been documented. In this work, we show that MCs are present in the cochleae of C57BL/6 mice and Wistar rats, where they localize in the modiolus, spiral ligament, and stria vascularis. The identity of MCs was confirmed in cochlear cryosections and flat preparations using avidin and antibodies against c-Kit/CD117, chymase, tryptase, and FceRI $\alpha$. The number of MCs decreased significantly during postnatal development, resulting in only a few MCs present in the flat preparation of the cochlea of a rat. In addition, exposure to $40 \mu \mathrm{M}$ cisplatin for $24 \mathrm{~h}$ led to a significant reduction in cochlear MCs. The presence of MCs in the cochlea may shed new light on postnatal maturation of the auditory periphery and possible involvement in the ototoxicity of cisplatin. Presented data extend the current knowledge about the physiology and pathology of the auditory periphery. Future functional studies should expand and translate this new basic knowledge to clinics.
\end{abstract}

Keywords: auditory periphery; mast cell; cochlea

\section{Introduction}

Mast cells are part of the innate immune system of myeloid lineage and are derived from the bone marrow, from where they home to the mucosal tissues, or from the fetal liver, from where they home to the connective tissues [1,2]. Mature MCs are present in peripheral organs such as the lung [3], intestine [4], heart [5], eye [6], brain [7], and in many other structures [8]. MCs produce a variety of unique proteins and substances used for their identification [9]. Some of them, such as c-Kit receptor for MGF (Mast Cell Growth Factor, also called Stem Cell Factor), designated CD117, are expressed on the cell surface. Some others are localized in the mast cell secretory granules. The granule-localized substances include heparin, mast cell tryptases, mast cell chymases, and other proteases $[10,11]$, immune mediators, and neuromodulators [11-14].

In addition to their well-explored role in allergic responses [15], MCs are involved in the regulation of vascular permeability [16], autoimmune diseases [17], and various stress-related and neurodegenerative conditions, including depression [18] and Alzheimer's disease [19]. This involvement is possible due to the capacity of MCs to interact with an array of cell types, including, but not limited to, lymphocytes [20], neurons [21], microglia [22], and epithelium [23]. The diversity of stimuli to which MCs are capable 
of reacting to, and the wealth of cell types that can respond to the MC mediators, make them potent regulators of local and systemic physiological and pathological reactions.

In the sensory organs, the presence of MCs has been reported in the nasal mucosa [24,25], in the ocular tissues [26], and the gustatory tissues [27]. In the inner ear, MCs were detected in the endolymphatic sac of humans and guinea pigs [28,29]. In addition, degranulated MCs were observed in the lumen of the endolymphatic sac of guinea pigs after allergen-mediated induction of hypersensitivity type I [30] that was functionally associated with endolymphatic hydrops.

To our best knowledge, no published research has focused on the presence of MCs in the cochlea up to now. We reasoned that this topic could be essential to explore to advance our understanding of the inner ear biology and pathology. Therefore, we initiated this study, in which we performed a systematic search for MCs.

\section{Materials and Methods}

\subsection{The Animals}

This study was carried out in accordance with the recommendations of the EU Directive 2010/63/EU on the protection of animals used for scientific purposes. The experimental protocol was approved by the Governmental Ethics Commission for Animal Welfare (LaGeso Berlin, Germany; approval numbers: T 0234/00, T 0292/16, and T 0235/18). Newborn Wistar rats (outbred animal strain) and C57BL/6 mice were purchased from the local animal facility (the research service facility within the Charité-Universitätsmedizin Berlin responsible for experimental animal breeding and keeping, animal transport, animal welfare, and veterinary services). The animals were of both genders and were 1, 3, 5, 7, 9 days old (total $n=120$ for Wistar rats and $n=80$ for C57BL/ 6 mice). The experiments with 30-day-old animals (each $n=20$ for Wistar rats and C57BL/6 mice) were conducted in accordance with international guidelines and the $3 \mathrm{R}$ program (Reduce, Refine, Replace).

\subsection{Cryosections}

For the cryosections, the base of the skull with both temporal bones was prepared. The specimens were fixed overnight in $4 \%$ formalin at $+4{ }^{\circ} \mathrm{C}$, and the temporal bones from 30-day-old animals were additionally incubated in 20\% EDTA solution pH 7.4 (Carl Roth GmbH + Co. KG, Karlsruhe, Germany) for three days at $+4{ }^{\circ} \mathrm{C}$, and washed in $0.1 \mathrm{M}$ PBS. Subsequently, the tissue was incubated in $15 \%$ and $30 \%$ sucrose solution at $+4{ }^{\circ} \mathrm{C}$ for three days. Next, the specimens were placed in an aluminum box containing the Optimal Cutting Temperature (OCT) tissue freezing medium (cat. \#0201 08926, Leica, Wetzlar, Germany). The tissue was shock-frozen in liquid nitrogen and then kept at $-20{ }^{\circ} \mathrm{C}$. Then, 7-10 $\mu \mathrm{M}$ cryosections were prepared using cryostat Leica CM 3050S (Germany). The sections were stored at $-20^{\circ} \mathrm{C}$ until further processing.

\subsection{Explant Cultures and Flat Preparations of the Cochleae}

The explants were prepared as previously described [31]. Briefly, following decapitation, the cochlea was dissected from the temporal bone and placed under the stereoscope SteREO Discovery.V8 (Carl Zeiss, Germany) to isolate the membranous cochleae. After removing cartilage, bone capsule, stria vascularis, and spiral ligament, the membranous cochleae were divided into three equal parts: an apical, medial and basal. Each section contained modiolus, spiral limbus with spiral ganglion neurons, and the organ of Corti. Cochlear tissues were explanted in the 4-well culture dishes containing $500 \mu \mathrm{L}$ of tissue culture medium (DMEM/F12; (cat. \#21331-020, Gibco ${ }^{\circledR}$, Karlsruhe, Germany), supplemented with 10\% fetal bovine serum (FBS, cat. \#S0113, Biochrom AG, Berlin, Germany), 2.5 M glucose (cat. \#G8769, Sigma, Aldrich, Germany), insulin-transferrin-Na-selenite (cat. \#11207500, Roche, Basel, Switzerland), penicillin G (cat. \#A321-42, Biochrom AG, Berlin, Germany), and IGF-1 (\#4326-RG R\&D Systems, Wiesbaden, Germany). The culture was conducted in a humidified incubator at $+37{ }^{\circ} \mathrm{C}$ and $5 \% \mathrm{CO}_{2}$ for $24 \mathrm{~h}$. The explants were fixed in $10 \%$ formalin (cat. \#HT5011, 
Sigma-Aldrich, Darmstadt, Germany) for $40 \mathrm{~min}$ at room temperature (RT) and kept at $+4{ }^{\circ} \mathrm{C}$ for future immunohistochemical/immunofluorescence (IHC/IF) staining. The explanted membranous cochlear tissues (flat preparations) were used for staining and scoring of MCs because of the complete view of the basilar membrane with the organ of Corti, spiral limbus, and the spiral ganglion neurons as opposed to the cryosections or paraffin sections that were prepared to achieve a cross-sectional view through the cochlea.

\subsection{Exposure to Cisplatin}

The cisplatin (cis-diamminedichloridoplatinum II, cat. \#CAS 15663-27-1, Calbiochem, Merck, Darmstadt, Germany) was dissolved in dimethyl sulfoxide (DMSO) to achieve a concentration of $100 \mathrm{mg} / \mathrm{mL}$. A stock solution $(3.33 \mathrm{mM})$ was prepared by diluting the cisplatin at $1 \mathrm{mg} / \mathrm{mL}$ of the tissue culture media. Cochlear explants dissected from p5 (5th postnatal day) Wistar rats were cultured as described above for $24 \mathrm{~h}$ in the 4 -well plates with cisplatin in concentrations of 10, 20, and $40 \mu \mathrm{M}$. Explants cultured without cisplatin served as negative controls.

\subsection{Paraffin Embedding}

For paraffin embedding, the isolated bases of skulls containing both temporal bones were fixed overnight in $4 \%$ formalin at $+4{ }^{\circ} \mathrm{C}$. The temporal bones from 30-day-old animals were additionally and subsequently incubated in 20\% EDTA solution pH 7.4 (Carl Roth GmbH + Co. KG, Karlsruhe, Germany) for three days at $+4{ }^{\circ} \mathrm{C}$, washed in 0.1 M PBS, and embedded in paraffin using KD-500 tissue processor (Roundfin, China). Then, $10-\mu \mathrm{M}$-thick paraffin sections were prepared using Microm HM $355 S$ (Leica), followed by deparaffinization in xylene and a series of ethanol before staining.

\subsection{Immunofluorescent Staining}

The specimens (cryo- and paraffin-embedded sections) were washed with 0.1 M PBS, permeabilized with $0.25 \%$ Triton X-100 (Fluka) in PBS and blocked with 4\% normal goat serum (NGS, Jackson) to prevent the non-specific antibody binding for $60 \mathrm{~min}$ at RT, as previously described [32]. After this step, the specimens were incubated with the antibodies against the target molecule (for detailed information about the antibodies, see Table 1) for $30 \mathrm{~min}$ at $+37^{\circ} \mathrm{C}$ in a staining buffer containing 0.1 PBS, $0.1 \%$ Triton X-100, and 1\% NGS. Next, the secondary antibodies conjugated with a fluorescent dye were applied for $60 \mathrm{~min}$ at RT. For the detection of heparin-containing granules, the specimens were incubated with avidin conjugated to AlexaFluor-488 (Invitrogen), whereas the nuclei were labeled with DAPI (Dianova, Hamburg, Germany). ProLong Gold Antifade Mountant was added to fix the coverslip in place and to prevent fluorescence fading. As a positive control, thymus tissues were used (data not shown). In negative controls, the primary antibody was omitted.

\subsection{Light, Epifluorescent and Confocal Microscopy}

Digital imaging was performed using an epifluorescence microscope EVOS FL Cell Imaging System (Thermo Fisher Scientific, Waltham, MA, USA) with $\times 10, \times 20$, and $\times 40$ objectives. Light microscopy was performed on BX51 Olympus microscope (Tokio, Japan). Confocal images were made using confocal microscope Leica TCS SP5 (Leica Microsystems, Wetzlar, Germany) with immersion oil objectives $\times 40$ and $\times 63$. The Alexa-488, Alexa-594, and DAPI were excited using argon-laser (488 nm), helium-neon laser $(543 \mathrm{~nm})$, and blue diode laser $(405 \mathrm{~nm})$, respectively. The images were pseudocolored with RGB tools and reconstructed with ImageJ software (http://rsb.info.nih.gov/ij/). The quantitative image analyses (cell size) were performed using ImageJ software (https://imagej.nih.gov/). 
Table 1. Primary and secondary antibodies and dyes.

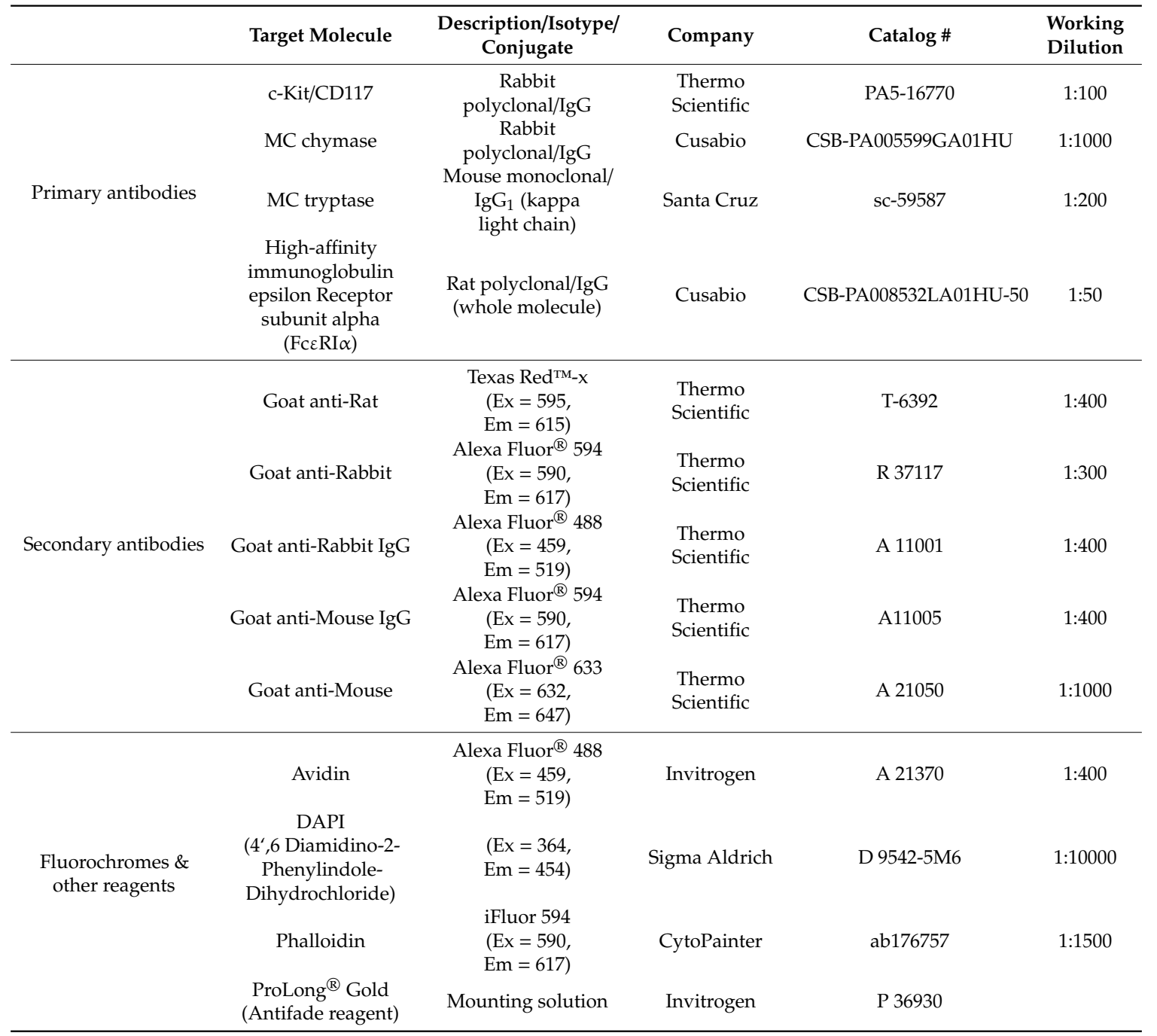

\subsection{Western Blot}

The cochlear lysates were prepared with membranous cochlea by placing them in microcentrifuge tubes containing $80 \mu \mathrm{L}$ RIPA buffer (Cell Signaling, \#9806). The lysates were then clarified by centrifugation at $14.000 \mathrm{rpm}$ for $10 \mathrm{~min}$ at $+4{ }^{\circ} \mathrm{C}$. The concentration of protein was determined using the Micro BCA protein assay kit (Thermo Fisher Scientific, Darmstadt, Germany, \#23235). The aliquots containing $6 \mu \mathrm{g}$ of total protein (p1, p3, p5, p7, p9) were mixed with Roti-Load sample loading solution (ROTH, \#K929.1) and heated at $90{ }^{\circ} \mathrm{C}$ for $5 \mathrm{~min}$ in a Thermomixer comfort (Eppendorf Vertrieb, Hamburg, Germany), then transferred onto Novex WedgeWell 4-20\% Tris-Glycine Mini Gels 12-well (Thermo Fischer Scientific, Darmstadt, Germany, \#XP04202BOX) and 15-well Novex WedgeWell 4-20\% Tris-Glycine Mini Gels (Thermo Fischer Scientific, Darmstadt, Germany \#XP04205BOX) using a mini-SDS-PAGE system XCell SureLock Electrophoresis Cell (Invitrogen, Carlsbad, CA, USA \#1287724-0959) at $130 \mathrm{~V}$ for $1 \mathrm{~h}$ and $40 \mathrm{~min}$. The protein marker used was a PageRuler Plus Prestained Protein Ladder (Thermo Fischer Scientific, Darmstadt, Germany, \#26619). After the electrophoresis, resolved proteins were transferred onto 0,45 $\mu \mathrm{m}$ Immobilon-P Transfer Membrane (Millipore, Darmstadt, Germany, \#IPFL 000 10) using XCell II Blot Module (Invitrogen, \#E19051) at $300 \mathrm{~mA}$ for $44 \mathrm{~min}$ (Biometra $\mathrm{GmbH}$, Göttingen, Germany). The membranes were blocked with $5 \%$ skimmed milk powder solution prepared in PBS and containing 0.1\% Tween 20 (Sigma-Aldrich, Taufkirchen, Germany, \#524653-1EA) for one hour at RT followed by incubation for $2 \mathrm{~h}$ at RT with 
one of the primary rabbit antibodies anti-CD117 (Table 1). Following several washes in PBS 0.05\% Tween 20 for $10 \mathrm{~min}$, the secondary antibodies were added. The signal was detected by incubation of the blot with SuperSignal West Femto Maximum Sensitivity Substrate (ThermoScientific, \#34095) and direct measurement of chemiluminescence by C-Digit scanner (LI-COR Biotechnology-GmbH, Bad Homburg vor der Höhe, Germany). The quantification was done with GelScan Pro V.6.0 software.

\subsection{Statistical Analyses}

Statistical analyses were performed using SigmaPlot software version 13.0 (Systat Software GmbH, Erkrath, Germany). The descriptive statistics were generated for the entire data set. The significance of differences between the means of cochlear MCs scored on different postnatal days was tested using Student's t-test or one-way ANOVA; the alpha value was set to 0.05 .

\section{Results}

\subsection{Avidin-Positive Cells Are Present in the Cochleae of Mice and Rats}

MCs were visualized in the cochlea using staining of cochlear paraffin sections derived from mice and rats with avidin-AlexaFluor-488 [33]. The avidin-positive, granulated cells were identified in modiolus and spiral limbus of both species (Figure 1). Occasionally, avidin-positive cells were visible in close proximity to the Reissner's membrane (Figure 1C-mouse, arrow, and Figure 1E, rat, arrow) from the side of the scala vestibuli. No MCs were detected in or close to the organ of Corti (OC). No free scattered MCs (outside the tissue section) were seen; all MCs were located within the tissues. The bright-field microscopy (Figure 1F) and immunofluorescence (Figure 1G) show the presence of mast cells within the cochlear bone cavity.
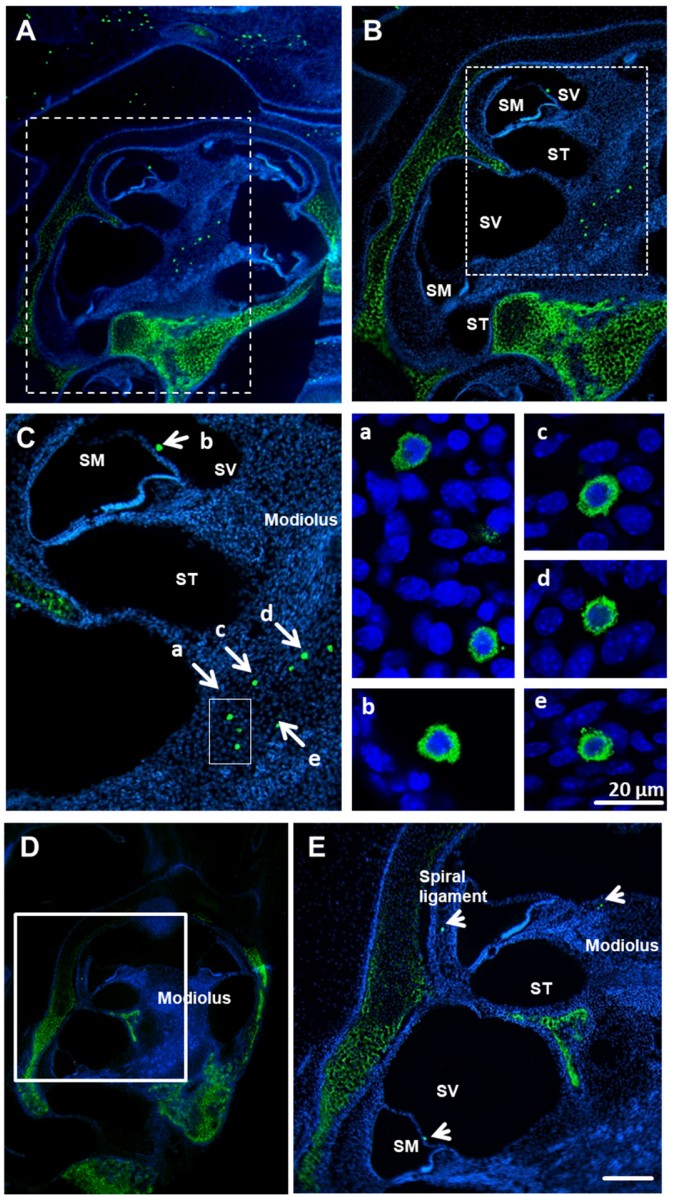

Figure 1. Cont. 


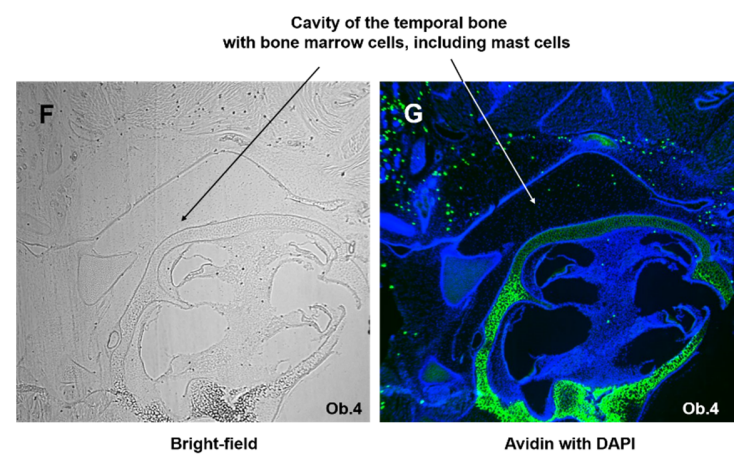

Figure 1. Avidin-positive MCs (mast cells) are present in the cochleae of mice and rats. MOUSE: Low (A), medium (B) and high (C) magnification of whole cochlear (p3 mice, $n=6$ ) paraffin-embedded sections $(10 \mu \mathrm{m})$ labeled with avidin-AlexaFluor-488 (green) and DAPI (blue). Avidin-positive MCs in scala vestibuli and modiolus; nuclei counterstained with DAPI. (C). Enlarged images of various cochlear MCs (a-e from panel C); scale bar $20 \mu \mathrm{m}$. RAT: Low (D) and medium (E) magnification of whole cochlear (p3 rat, $n=6)$ paraffin-embedded sections $(10 \mu \mathrm{m})$ labeled with avidin-AlexaFluor-488 (green) and DAPI (blue). Avidin-positive MCs are visible in modiolus and the spiral ligament. Scale bar $50 \mu \mathrm{m}$. SM—scala media, ST—scala tympani, SV—scala vestibuli. There is visible staining of cartilage due to the known affinity of avidin to cartilage tissues [34]. Low magnification of bright field (F) and fluorescent field $(\mathbf{G})$ representing paraffin-embedded sections $(10 \mu \mathrm{m})$ labeled with avidin-AlexaFluor-488 (green) and DAPI (blue). The micrograph of the bright field demonstrates that the mast cells are localized to the cochlear bone tissue, which is not visible when using fluorescence.

\subsection{The Avidin-Positive Cochlear Cells Express CD117}

Next, the presence of transmembrane tyrosine-kinase receptor CD117 (c-kit) was investigated in avidin-positive cochlear cells of Wistar rats. Flat preparations of cochlear tissues were incubated with avidin conjugated with Alexa Fluor ${ }^{\circledR} 488$ and with rabbit IgG directed against CD117 followed by incubation with the secondary antibody against rabbit IgG conjugated with Alexa Fluor ${ }^{\circledR} 594$. The representative micrograph of the modiolus region verified the localization of CD117 signal on the avidin-positive cells (Figure 2A,B). The expression of CD117 antigen was consistent with the surface expression.

\subsection{Cochlear MCs Express Tryptase, Chymase, and the High-Affinity Immunoglobulin Epsilon Receptor Subunit Alpha}

The MCs produce tryptase and accumulate it in the granules. To determine if tryptase is present in the avidin-positive cells, tryptase-specific staining was performed with cochlear specimens obtained from $\mathrm{p} 3$ Wistar rats. The experiments confirmed the presence of tryptase within the cytoplasmic granule of avidin-positive cochlear cells, further confirming their identity as MCs (Figure 2C). An additional $\mathrm{MC}$ marker is chymase. Because of the lack of suitable reagents to perform the immunostaining in rat tissues, mouse cochlear tissues (flat preparations) were stained with antibodies against chymase. The staining confirmed that the avidin-positive cochlear MCs contain chymase. The chymase-positive cells were detected in the cochleae of p2 and p30 mice (Figure 2D). Another MC marker, high-affinity immunoglobulin epsilon receptor subunit alpha ( $\left.F_{c \varepsilon R I} \alpha\right)$, was also seen in the mouse cochlear flat preparations (Figure 3). 
A
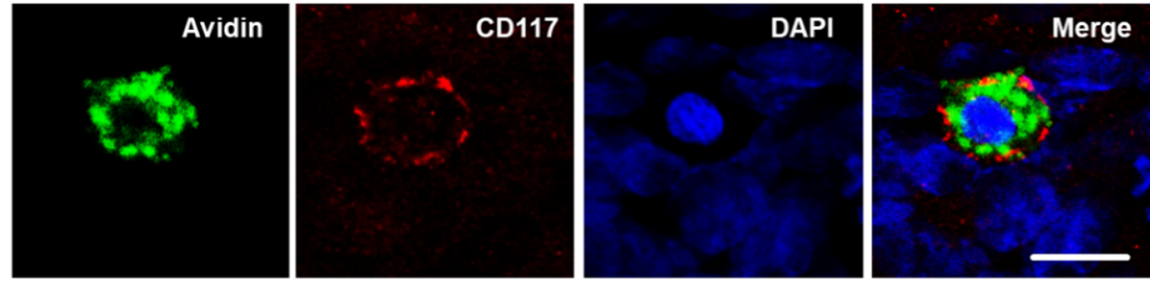

B
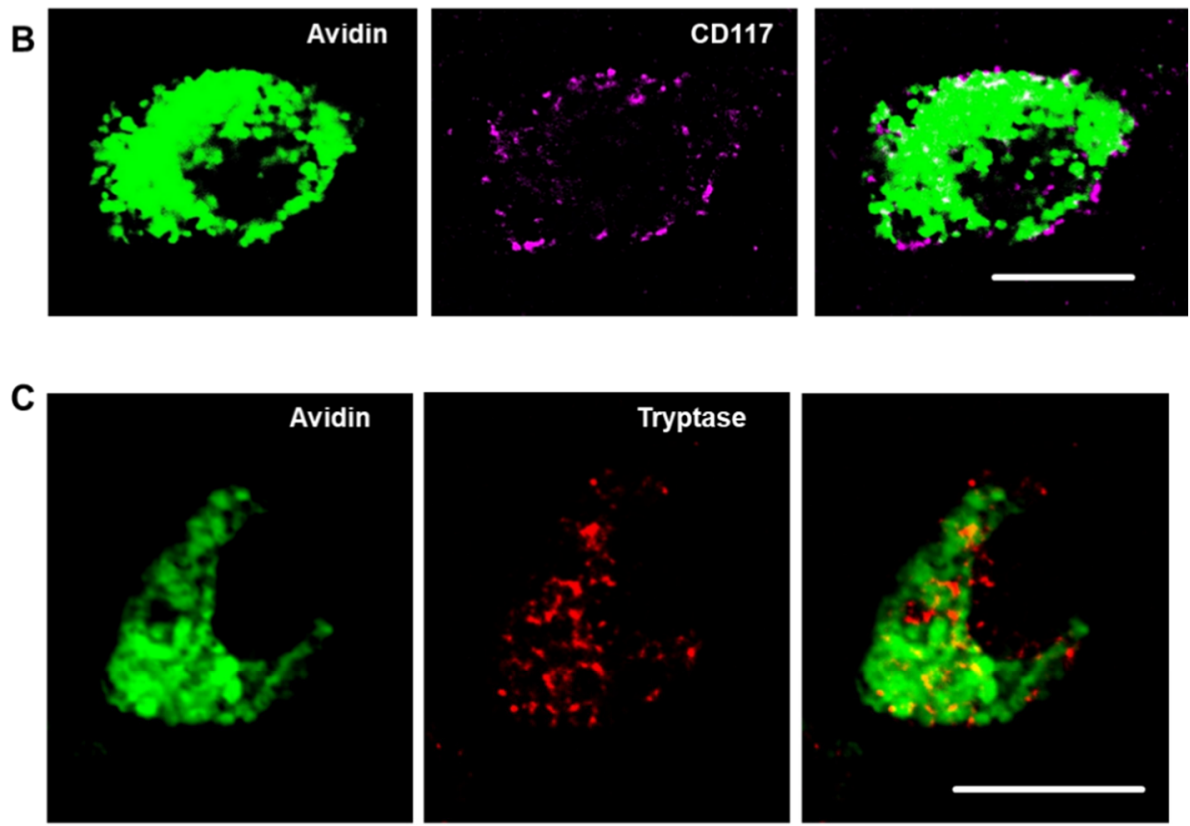

D
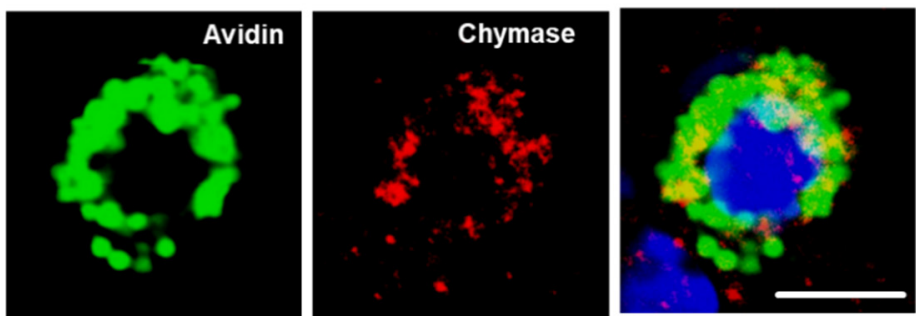

Figure 2. CD117, tryptase, and chymase are expressed by cochlear MCs. Representative confocal images of cochlear MCs that were immunopositive for CD117 (red / magenta) (A,B), tryptase (red) (C) and chymase (red) (D). MCs were detected with Alexa Fluor ${ }^{\circledR} 488$-conjugated avidin (green). Nuclei in (A,D) were counterstained with DAPI (blue). Images depicted from the modiolus region of medial turn from $\mathrm{p} 3$ rat cochlea. Images $(\mathbf{A}-\mathbf{C})$ were obtained from $\mathrm{p} 3$ Wistar rats; image (D) was obtained from p30 mouse. Scale bars $10 \mu \mathrm{m}$.

\subsection{Levels of c-Kit/CD117 Protein in the Cochlea Change During the First Nine Postnatal Days}

The level of $145 \mathrm{kDa}$ CD117 protein in the membranous cochlear explants (containing basilar membrane, the organ of Corti, spiral limbus, and spiral ganglion neurons) was determined using Western blotting. The results demonstrated a statistically significant increase of CD117 in the cochleae of 5- and 7-day-old rats compared to the first, third, and the ninth day of life (Figure 4). As a positive control, the thymus from the same experimental animals was used. In contrast, CD117 was expressed in the thymus (control tissue containing MCs) on even levels during all studied post-developmental days. 

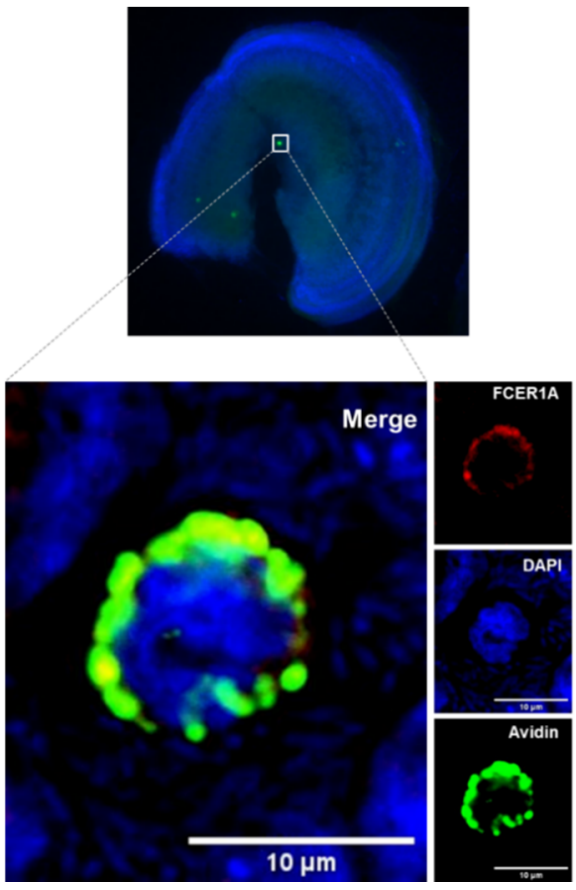

Figure 3. Cochlear MCs express the high-affinity immunoglobulin epsilon receptor subunit-alpha $\left(F_{c \varepsilon R I} \alpha\right)$. The image shows a cochlear explant of $\mathrm{p} 3$ mouse stained with an antibody against FceRI $\alpha$ (red), avidin (green), and DAPI (blue).

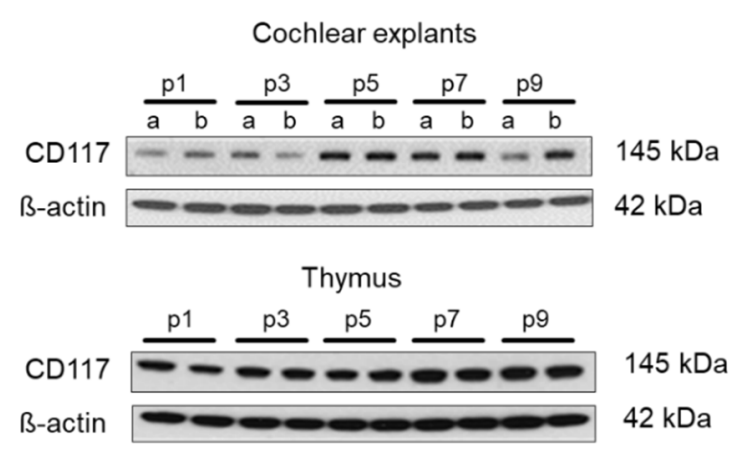

(A)
Differences in cochlear CD117 levels during postnatal development of Wistar rats

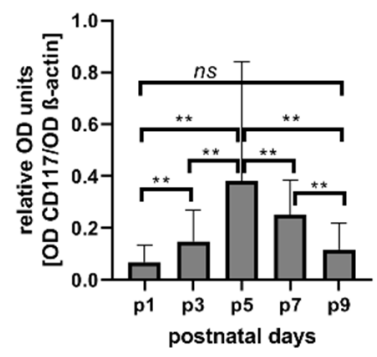

(B)

Figure 4. The levels of CD117 in the cochlea of Wistar rats vary during postnatal development. (A) Representative Western blot (WB) images showing CD117 (MW $142 \mathrm{kDa}$ ) expression in cochlear explants (A upper panel) and the thymus (A lower panel) isolated from naïve Wistar rats (p1-p9). $\beta$-actin (MW $42 \mathrm{kDa}$ ) was used as loading control; $6 \mu \mathrm{g}$ proteins per lane were loaded. In the cochlear panel: $\mathrm{a}$-apical, $\mathrm{b}$ - basal turn of the cochlea. In the thymus panel, each line corresponds to a different tissue sample. (B) Optical density (OD) of each sample $(n=16$ cochleae for each developmental time point) was measured and expressed as the OD of CD117 divided by the OD of ß-actin from the same sample. The statistical analysis indicated significant differences between the CD117 expression on the consecutive developmental days (one-way ANOVA, F $(4,75)=4.819$, ${ }^{* *} p=0.0016$ ). ns: No statistical difference was detected between the OD of CD117 on p1 and p9 (Mann-Whitney test).

\subsection{The Number of MCs in Cochlear Explants Decreases During Postnatal Maturation of Rat}

The next question was if the number of MCs in the cochlear tissue remains constant or if it changes during the postnatal development of cochlea. Comparative analyses demonstrated an age-dependent decrease of the cochlear MC numbers. The flat cochlear preparations (Figure 5A) obtained from the 
inner ear of p1 Wistar rats contained significantly more MCs $(p<0.01)$ when compared to the explant of $\mathrm{p} 9$ Wistar rats. In detail, one day after birth, there were on average 17.6 MCs per flat preparation of cochlea (SD +/- 12.3). P3 animals had on average 14.7 MCs (SD +/- 8.6), p5 animals 9.8 MCs (SD +/- 6.2), p7 animals 4.7 MCs (SD +/- 3.5), and p9 animals had 2.6 MCs (SD +/- 2.1) (Figure 5B).

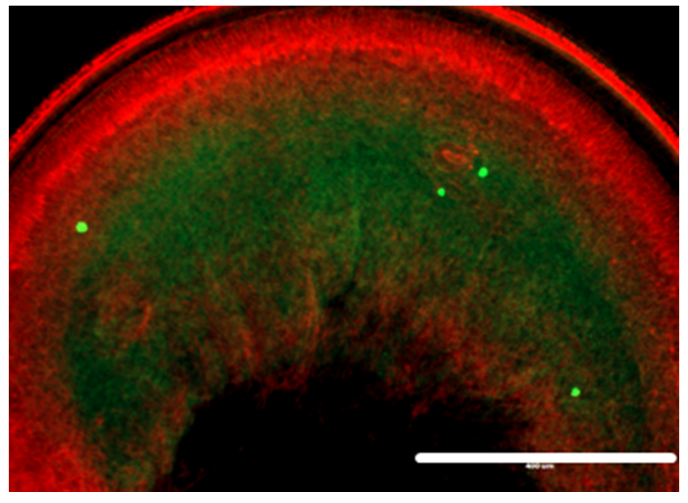

(A)

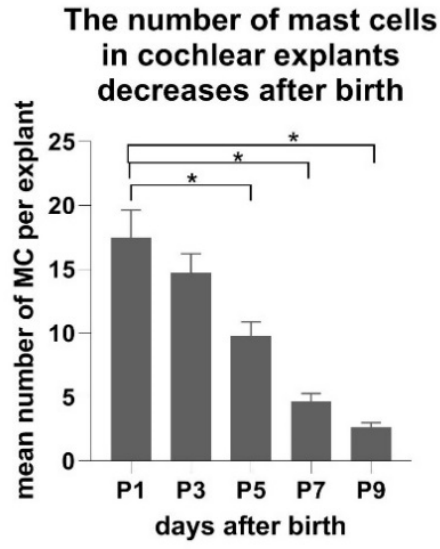

(B)

Figure 5. The number of cochlear MCs of Wistar rats decreases during postnatal development (p1-p9). (A) An exemplary micrograph of MCs visualized in the flat preparation of cochlear explants with avidin-AlexaFluor ${ }^{\circledR} 488$ and phalloidin-Texas red $^{\mathrm{TM}}$ (to stain filamentous actin). Scale bar $400 \mu \mathrm{m}$. (B) Quantification of MC numbers in the flat cochlear preparations of naïve p1-p9 Wistar rats. Presented are the average values, whiskers $+/-\mathrm{SD}$. Significance: ${ }^{*} p<0.01$ (one-way ANOVA). Sample size (cochleae): p1 $n=32, \mathrm{p} 3 n=32, \mathrm{p} 5 n=32, \mathrm{p} 7 n=32, \mathrm{p} 9 n=32$.

\subsection{The Number of MCs in Cochlear Explants Changes upon Exposure of Cochlear Explants to Cisplatin}

In the last part of the experiments, the impact of cisplatin on the presence of MCs was investigated. Cisplatin is an ototoxic medication triggering hearing loss in a significant proportion of cancer patients via induction of hair cell loss in high frequencies. In laboratory settings, cochlear explants obtained from experimental animals (mice or rats) are commonly used to study in vitro the mechanisms of ototoxicity in the hair cells. However, cisplatin can affect other cells in the cochlea, such as marginal cells, perivascular resident macrophage-like melanocytes, and basal cells of the stria vascularis [35]. Therefore, we wanted to determine the effect of cisplatin exposure on the cochlear MCs. Cochlear explants obtained from p5 Wistar rats were exposed for $24 \mathrm{~h}$ to various concentrations of cisplatin $(10,20$, and $40 \mu \mathrm{M})$. After exposure, the flat cochlear preparations were stained with avidin to visualize and score the MCs and phalloidin to visualize the hair cells. The concentration of $10 \mu \mathrm{M}$ cisplatin did not cause significant hair cell loss (Table 2) nor induce substantial changes in the MC numbers (Figure 6). Cisplatin used at $20 \mu \mathrm{M}$ induced a significant hair cell loss (about 50\%) and was associated with a higher number of cochlear MCs. Cisplatin at the concentration of $40 \mu \mathrm{M}$ induced a loss of about $70 \%$ of the hair cells. Under these conditions, significantly lower numbers of MCs were observed in the cochlea. 
Table 2. Influence of cisplatin on the hair cell loss. Shown are the average numbers of intact inner and outer hair cells per $100 \mu \mathrm{m}$ in the apical, medial, and basal parts of the explants. Significant differences compared to the control sample were calculated with one-way ANOVA; significance ${ }^{* *} p<0.01$; n.s.-not significant.

\begin{tabular}{ccccccc}
\hline & & Inner Hair Cells & & Outer Hair Cells \\
\hline Conditions & Apical & Medial & Basal & Apical & Medial & Basal \\
\hline Control $(n=6)$ & $9.56 \pm 0.58$ & $0.28 \pm 1.02$ & $10.00 \pm 0.69$ & $12.33 \pm 0.54$ & $11.72 \pm 0.54$ & $11.37 \pm 1.33$ \\
$10 \mu \mathrm{M}$ cisplatin $(n=6)$ & $8.78 \pm 1.10$ (n.s.) & $9.11 \pm 1.04$ (n.s.) & $9.83 \pm 0.81$ (n.s.) & $12.20 \pm 0.93$ (n.s.) & $11.56 \pm 0.58$ (n.s.) & $11.02 \pm 0.46($ n.s.) \\
$20 \mu \mathrm{M}$ cisplatin $(n=6)$ & $6.17 \pm 0.35^{* *}$ & $7.61 \pm 0.92^{* *}$ & $4.94 \pm 1.71^{* *}$ & $8.54 \pm 1.32 * *$ & $9.31 \pm 1.32^{* *}$ & $5.74 \pm 0.31^{* *}$ \\
$40 \mu \mathrm{M}$ cisplatin $(n=6)$ & $4.78 \pm 0.40^{* *}$ & $4.89 \pm 2.74^{* *}$ & $3.83 \pm 0.86^{* *}$ & $3.69 \pm 1.84^{* *}$ & $4.87 \pm 2.99^{* *}$ & $3.35 \pm 1.02^{* *}$ \\
\hline
\end{tabular}

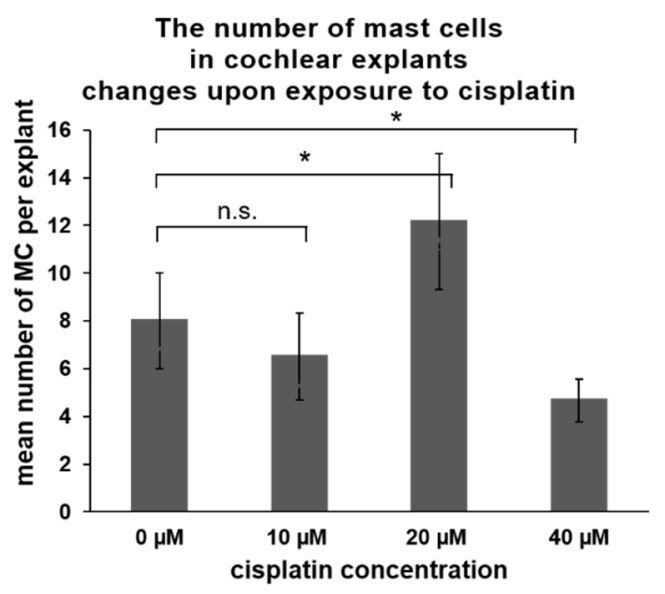

Figure 6. Cisplatin exposure-induced changes in a number of cochlear MCs of Wistar rats (p5). The explants ( $n=6$ per treatment) were exposed to various concentrations of cisplatin. The numbers of cochlear MCs were scored and are presented as an average value (whiskers +/- SD). A significant increase in the MC number was observed when $20 \mu \mathrm{M}$ cisplatin was used, whereas a decrease was observed when $40 \mu \mathrm{M}$ cisplatin was used. Significance: ${ }^{*} p<0.05$, Student's-t test; n.s. - not significant.

\section{Discussion}

The current study demonstrates that under normal physiological conditions, MCs are present in the cochleae of rats and mice. The MCs were detected in modiolus, spiral limbus, and close to the Reissner's membrane from the side of the scala vestibuli. No MCs were identified in the organ of Corti. The MCs were located within the cochlear tissues, consistent with the status of the resident cells. The numbers of cochlear MCs scored in the flat preparations containing basilar membrane, the organ of Corti, spiral limbus, and the spiral ganglion neurons decreased during the postnatal development of Wistar rats. Furthermore, exposure to cisplatin significantly affected their numbers. Our data complement and extend earlier scarce reports on the existence of MCs in the inner ear [28,30].

The identity of cochlear MCs was verified using various methods. The first method was a double-staining with avidin and an antibody against CD117. Avidin is a protein with a high affinity to heparin [36]. Glycosaminoglycan abundantly presents in the granule of MCs [37], whereas CD117 is a receptor tyrosine kinase present on a surface of MCs, hematopoietic stem cells, and various types of cancer cells, confirming its role as a proto-oncogene [38]; it is also detected on melanocytes. Melanocytes that migrate during embryonal development into stria vascularis contribute to cochlear homeostasis by participation in potassium recycling, thus preserving the endocochlear potential [39]. Therefore, it could be possible that the CD117-positive staining identified cochlear melanocytes (intermediate cells in the stria vascularis). However, melanocytes do not contain heparin detected by avidin, and for the experiments when CD117 detection was employed, such as immunofluorescence in the flat cochlear preparations or the Western blot, only the stria vascularis-free preparations were used. Other molecules used to verify the identity of the cochlear MCs were the mast cells tryptase and chymase [10]. Both proteases participate in tissue remodeling, wound healing, and allergic 
reactions [40]. Although the roles of tryptase and chymase have not yet been studied in cochlear physiology or pathology, one can speculate that these mast cell proteases could participate in cochlear tissue remodeling during the growth and development of cochlea or after injury. Lastly, the expression of high-affinity immunoglobulin epsilon receptor subunit-alpha $F_{C} \varepsilon R I \alpha$ on the surface of the cochlear avidin-positive cells ultimately confirms the identity of these cells as MCs.

The biological purpose of cochlear MCs is currently unclear. It would be tempting to speculate that the MCs play a dual role in the auditory periphery. Because the primary physiological function of mast cells is to control tissue homeostasis [41], the first hypothetical task of cochlear MCs could be participation in homeostasis and functional maturation of rodent cochlea. The second role of cochlear mast cells could be participation in innate and adaptive immunity [42,43]. Past research, which was restricted to the endolymphatic sac, demonstrated that the sensitization of guinea pigs with allergens leads to the IgE-mediated degranulation of MCs to the perisaccular connective tissues, accompanied by endolymphatic hydrops [30]. In addition, few clinical studies describing the presence of MCs in perisaccular connective tissue of the inner ear explain the clinical association between allergy and inner ear disorders [28-30]. The degranulation of MCs can be triggered not only by IgE antibodies but also by other stimuli (e.g., temperature, neurotrophins) to induce a spill of cytokines [13], proteases [44], heparin, and histamine [45]. Histamine receptors have been identified in the inner ear of guinea pigs [46], rats [47], mice [48], and in the human inner ear [49], including the cochlear tissues. In guinea pigs, histamine applied to the cochlear perilymph influenced the compound action potential in a dose-dependent manner [46]. In contrast, in the vestibular organ of frogs, histamine has increased the evoked afferent firing rate of the ampullar nerve, consistent with its ability to induce vertigo [50].

The interesting aspect revealed by the present study is the significant decrease in the numbers of cochlear MCs observed in the flat cochlear preparations. This reduction occurred during the maturation of rodent cochlea ( $\mathrm{p} 1$ to $\mathrm{p} 9$ ). This finding might be explained by recent studies demonstrating the involvement of MCs in the physiological development of the cornea of mice by participation in the tissue vascularization and maturation of corneal nerve fibers [51]. The numbers of corneal MCs observed during embryonic development gradually increased from E14.5 to E20.5, followed by a decrease and a complete absence from day 13 after birth. Based on the above knowledge, it is tempting to speculate that also in the cochlea, the MCs might contribute to the maturation of spiral ganglion fibers, and after the final maturation stage is achieved, the numbers of MCs decrease. Supporting this hypothesis is that MCs produce neurotrophins such as nerve growth factor (NGF) [52], which is essential for proper postnatal development of spiral ganglion neurons [53]. Moreover, MCs produce histamine and serotonin, and both neurotransmitters could contribute to the final tuning of the peripheral auditory system during the first two weeks of the rodent's life. Such a notion is supported by an observation made in the CNS about the mast-cell-derived serotonin being essential for the maturation of hippocampal neurons [54]. Further, in the thymus, duodenum, and the mammary gland, the presence and numbers of MCs are associated with the proper function and development of these organs [55], which could also be the case for cochlea. Helpful for understanding the physiology of cochlear MCs would be the investigation of their presence, numbers, and function in the prenatal cochlea.

The last aspect of the presented study regarded the impact of cisplatin on the cochlear MCs. Cisplatin, a common cytostatic medication used to treat various types of tumors, induces toxicity in the kidney and the auditory periphery [56]. The ototoxic mechanism attributed to cisplatin involves elevated reactive oxygen species leading to hair cell loss, particularly in the basal region responsible for the transduction of high frequencies. Not only hair cells but also other cell types (e.g., in the stria vascularis) can be negatively affected by cisplatin. Here, in addition to the expected hair cell loss (Table 2), we observed dose-dependent fluctuation in the cochlear MC numbers upon $24 \mathrm{~h}$ exposure to 10,20 , or $40 \mu \mathrm{M}$ cisplatin. Cisplatin at the concentration of $10 \mu \mathrm{M}$ did not cause either hair cell loss or change of MC numbers. At the concentration of $20 \mu \mathrm{M}$, significant hair cell loss was observed, and a substantial increase in MC numbers was noted. Exposure to cisplatin at the concentration of $40 \mu \mathrm{M}$ led to even greater hair cell loss and a significant decrease of MCs visualized with avidin. Cisplatin used 
at nanomolar concentrations was shown to induce histamine secretion from the murine MCs [57] but could also induce apoptosis in the human HMC-1 mast cell line [58] when used at the concentration of $10 \mu \mathrm{g} / \mathrm{mL}(33.3 \mu \mathrm{M})$, which is within the range used in the present work. Therefore, it can be assumed that the effect of cisplatin on the MCs ranges from degranulation to apoptosis, depending on its concentration. Notably, the degranulation of MCs is associated with the release of many neuronal and immune mediators into the immediate tissue environment. Such a release (for instance, of TNF-alpha) could amplify the cisplatin-induced damage. The degranulated (but not dead) MCs can no longer be detected by avidin, but after a certain time, the regranulation process would make them visible when using avidin staining. Further experiments should determine the effects of cisplatin on the cochlear MCs and clarify if MCs amplify cisplatin-induced ototoxicity.

Our work is not free of pitfalls. The first drawback is using the cochlear explants/flat preparations for MC scoring. That method left the numbers of MCs in the lateral wall and the modiolus unknown. However, using the cryosections (or paraffin sections) would require extreme workload and costs. Therefore, using new technologies such as iDisco [59] could, in the future, yield more information on the numbers and distribution of cochlear MCs in the intact tissues. Another drawback of this study was that we did not address the possible sexual dimorphism or inbred and outbred issues. However, prospective studies designed to answer the question about sex- or strain-related differences in the numbers or localization of cochlear MCs and their functional role in cochlear physiology should clarify this query.

\section{Conclusions}

In conclusion, we report here for the first time that MCs are present in the tissues of rodent cochleae. The localization of MCs in the cochlea included modiolus, spiral limbus, and spiral ligament. The numbers of MCs present in flat preparations (basilar membrane, the organ of Corti, spiral limbus, and spiral ganglion neurons) decreased during the postnatal development of Wistar rats. Furthermore, the relative levels of CD117 in flat preparations changed over time, being the greatest on p5. Lastly, cisplatin affected the numbers of cochlear MCs in the $\mathrm{p} 5$ cochlear flat preparations. Further experiments should shed more light on the function of MCs in cochlear development, homeostasis, and pathology.

Author Contributions: Conceptualization, A.J.S. and A.S.; methodology, A.J.S. and A.S.; formal analysis, T.D., A.J.S., A.S., and B.K.; investigation, A.J.S., T.D., A.S., V.S. and B.K.; resources, H.O. and A.J.S.; data curation, T.D., B.K., A.J.S., and A.S.; writing—original draft preparation, A.J.S., and A.S.; writing-review and editing, A.J.S., A.S., H.O., and B.K.; visualization, A.J.S., A.S. and T.D.; supervision, A.J.S., A.S. and H.O.; project administration, A.J.S.; funding acquisition, A.J.S. All authors have read and agreed to the published version of the manuscript.

Funding: This research was funded by the Performance-Based Funds LOM awarded by the Charité-Universitätsmedizin Berlin to A.J.S. Additional funding was received from the Sonnenfeld Foundation to A.J.S for the purchase of the tissue culture incubator used in this work.

Acknowledgments: The authors are grateful to Eva Peters and Marcus Maurer for their encouragement. We are thankful to Olga Hegend, Julia Fuchs, Christiane Kölske, and Rebeca Kirstein, for their excellent technical assistance. Special thanks to Yang Yu and Elisabeth Freutel for performing pilot experiments. We thank the Sonnenfeld Foundation for the general support of our research. We acknowledge support from the German Research Foundation (DFG) and the Open Access Publication Funds of Charité-Universitätsmedizin Berlin.

Conflicts of Interest: The authors declare no conflict of interest.

\section{References}

1. Dahlin, J.S.; Hallgren, J. Mast cell progenitors: Origin, development and migration to tissues. Mol. Immunol. 2015, 63, 9-17. [CrossRef] [PubMed]

2. Dwyer, D.F.; The Immunological Genome Project Consortium; Barrett, N.A.; Austen, K.F.; Immunological Genome Project Consortium. Expression profiling of constitutive mast cells reveals a unique identity within the immune system. Nat. Immunol. 2016, 17, 878-887. [CrossRef] [PubMed] 
3. Shanahan, F.; Macniven, I.; Dyck, N.; Denburg, J.A.; Bienenstock, J.; Befus, D. Human Lung Mast Cells: Distribution and Abundance of Histochemically Distinct Subpopulations. Int. Arch. Allergy Immunol. 1987, 83, 329-331. [CrossRef] [PubMed]

4. Befus, A.D.; Pearce, F.; Gauldie, J.; Horsewood, P.; Bienenstock, J. Mucosal mast cells. I. Isolation and functional characteristics of rat intestinal mast cells. J. Immunol. 1982, 128, 2475-2480. [PubMed]

5. Ali, H.; Pearce, F.L. Isolation and properties of cardiac and other mast cells from the rat and guinea-pig. Inflamm. Res. 1985, 16, 138-140. [CrossRef] [PubMed]

6. Smelser, G.K.; Silver, S. The distribution of mast cells in the normal eye. Exp. Eye Res. 1963, 2, $134-$ IN7. [CrossRef]

7. Dropp, J.J. Mast cells in mammalian brain. Cells Tissues Organs 1976, 94, 1-21. [CrossRef]

8. Da Silva, E.Z.; Jamur, M.C.; Oliver, C. Mast cell function: A new vision of an old cell. J. Histochem. Cytochem. 2014, 62, 698-738. [CrossRef]

9. Passante, E. Mast cell and basophil cell lines: A compendium. In Basophils and Mast Cells; Springer: Berlin/Heidelberg, Germany, 2014; pp. 101-113.

10. Atiakshin, D.; Buchwalow, I.; Samoilova, V.; Tiemann, M. Tryptase as a polyfunctional component of mast cells. Histochem. Cell Boil. 2018, 149, 461-477. [CrossRef]

11. Frossi, B.; Mion, F.; Sibilano, R.; Danelli, L.; Pucillo, C. Is it time for a new classification of mast cells? What do we know about mast cell heterogeneity? Immunol. Rev. 2018, 282, 35-46. [CrossRef]

12. Kubo, M. Mast cells and basophils in allergic inflammation. Curr. Opin. Immunol. 2018, 54, 74-79. [CrossRef] [PubMed]

13. Lin, T.J.; Enciso, A.; Bissonnette, E.Y.; Szczepek, A.; Befus, A.D. Cytokine and drug modulation of TNF alpha in mast cells. Adv. Exp. Med. Biol. 1996, 409, 279-285. [PubMed]

14. Naumova, E.M.; Sergeeva, V.E. Histochemical study of mast cells from the thymus of mice receiving ACTH1-24. Bull. Exp. Biol. Med. 2004, 138, 93-96. [CrossRef] [PubMed]

15. Caslin, H.L.; Kiwanuka, K.N.; Haque, T.T.; Taruselli, M.T.; Macknight, H.P.; Paranjape, A.; Ryan, J.J. Controlling mast cell activation and homeostasis: Work influenced by bill paul that continues today. Front. Immunol. 2018, 9, 868. [CrossRef]

16. Hendriksen, E.; Van Bergeijk, D.A.; Oosting, R.S.; Redegeld, F.A. Mast cells in neuroinflammation and brain disorders. Neurosci. Biobehav. Rev. 2017, 79, 119-133. [CrossRef] [PubMed]

17. Brown, M.A.; Weinberg, R.B. Mast cells and innate lymphoid cells: Underappreciated players in CNS autoimmune demyelinating disease. Front. Immunol. 2018, 9, 514. [CrossRef]

18. Georgin-Lavialle, S.; The French Mast Cell Study Group; Moura, D.S.; Salvador, A.; Chauvet-Gelinier, J.-C.; Launay, J.-M.; Damaj, G.; Côté, F.; Soucié, E.; Chandesris, M.-O.; et al. Mast cells' involvement in inflammation pathways linked to depression: Evidence in mastocytosis. Mol. Psychiatry 2016, 21, 1511-1516. [CrossRef]

19. Kempuraj, D.; Selvakumar, G.P.; Thangavel, R.; Ahmed, M.E.; Zaheer, S.; Raikwar, S.P.; Iyer, S.S.; Bhagavan, S.M.; Beladakere-Ramaswamy, S.; Zaheer, A. Mast cell activation in brain injury, stress, and post-traumatic stress disorder and Alzheimer's disease pathogenesis. Front. Neurosci. 2017, 11, 703. [CrossRef]

20. Hershko, A.Y.; Rivera, J. Mast cell and T cell communication; amplification and control of adaptive immunity. Immunol. Lett. 2010, 128, 98-104. [CrossRef]

21. Silver, R.; Curley, J.P. Mast cells on the mind: New insights and opportunities. Trends Neurosci. 2013, 36, 513-521. [CrossRef]

22. Skaper, S.D.; Giusti, P.; Facci, L. Microglia and mast cells: Two tracks on the road to neuroinflammation. FASEB J. 2012, 26, 3103-3117. [CrossRef] [PubMed]

23. Cairns, J.A.; Walls, A.F. Mast cell tryptase is a mitogen for epithelial cells. Stimulation of IL-8 production and intercellular adhesion molecule-1 expression. J. Immunol. 1996, 156, 275-283. [PubMed]

24. Blom, H.M.; Godthelp, T.; Fokkens, W.J.; Jan, A.K.; Holm, A.F.; Vroom, T.M.; Rijntjes, E. Mast cells, eosinophils and IgE-positive cells in the nasal mucosa of patients with vasomotor rhinitis An immunohistochemical study. Eur. Arch. Oto-Rhino-Laryngol. 1995, 252, S33-S39. [CrossRef] [PubMed]

25. Bentley, A.; Jacobson, M.; Cumberworth, V.; Barkans, J.; Moqbel, R.; Schwartz, L.; Irani, A.; Kay, A.; Durham, S. Immunohistology of the nasal mucosa in seasonal allergic rhinitis: Increases in activated eosinophils and epithelial mast cells. J. Allergy Clin. Immunol. 1992, 89, 877-883. [CrossRef] [PubMed]

26. Levene, R.Z. Mast cells and amines in normal ocular tissues. Investig. Ophthalmol. Vis. Sci. 1962, 1, 531-543. 
27. Kim, D.-J.; Roper, S.D. Localization of serotonin in taste buds: A comparative study in four vertebrates. J. Comp. Neurol. 1995, 353, 364-370. [CrossRef]

28. Sleeckx, J.P.; Shea, J.J.; Peremans, J.M. The mast cells of the inner ear. Acta Otorhinolaryngol. Belg. 1976, 30, 443-449.

29. Miyamura, K.; Kanzaki, Y.; Nagata, M.; Ishikawa, T. Provocation of nystagmus and deviation by type I allergy in the inner ear of the guinea pig. Ann. Allergy 1987, 58, 36-40.

30. Takeda, T.; Takeda, S.; Egami, N.; Kakigi, A.; Nishioka, R.; Yamasoba, T. Type 1 allergy-induced endolymphatic hydrops and the suppressive effect of leukotriene receptor antagonist. Otol. Neurotol. 2012, 33, 886-890. [CrossRef]

31. Yu, Y.; Szczepek, A.J.; Haupt, H.; Mazurek, B. Geldanamycin induces production of heat shock protein 70 and partially attenuates ototoxicity caused by gentamicin in the organ of Corti explants. J. Biomed. Sci. 2009, 16, 79. [CrossRef]

32. Smorodchenko, A.; Rupprecht, A.; Fuchs, J.; Gross, J.; Pohl, E.E. Role of mitochondrial uncoupling protein 4 in rat inner ear. Mol. Cell. Neurosci. 2011, 47, 244-253. [CrossRef] [PubMed]

33. Tharp, M.D.; Seelig, L.L.; E Tigelaar, R.; Bergstresser, P.R. Conjugated avidin binds to mast cell granules. J. Histochem. Cytochem. 1985, 33, 27-32. [CrossRef] [PubMed]

34. Bajpayee, A.G.; Wong, C.R.; Bawendi, M.G.; Frank, E.H.; Grodzinsky, A.J. Avidin as a model for charge driven transport into cartilage and drug delivery for treating early stage post-traumatic osteoarthritis. Biomaterials 2013, 35, 538-549. [CrossRef]

35. Cai, J.; Wu, X.; Li, X.; Ma, C.; Xu, L.; Guo, X.; Li, J.; Wang, H.; Han, Y. Allicin protects against cisplatin-induced stria vascularis damage: Possible relation to inhibition of Caspase-3 and PARP-1-AIF-mediated apoptotic pathways. ORL J. Otorhinolaryngol. Relat. Spec. 2019, 81, 202-214. [CrossRef] [PubMed]

36. Kett, W.C.; Osmond, R.I.W.; Moe, L.; E Skett, S.; Kinnear, B.F.; Coombe, D.R. Avidin is a heparin-binding protein. Affinity, specificity and structural analysis. Biochim. Biophys. Acta (BBA) Bioenergy 2003, 1620, 225-234. [CrossRef]

37. Mulloy, B.; Lever, R.; Page, C.P. Mast cell glycosaminoglycans. Glycoconj. J. 2016, 34, 351-361. [CrossRef] [PubMed]

38. Galli, S.J.; Tsai, M.; Wershil, B.K. The c-kit receptor, stem cell factor, and mast cells. What each is teaching us about the others. Am. J. Pathol. 1993, 142, 965-974.

39. Steel, K.P.; Barkway, C. Another role for melanocytes: Their importance for normal stria vascularis development in the mammalian inner ear. Development 1989, 107, 453-463.

40. Douaiher, J.; Succar, J.; Lancerotto, L.; Gurish, M.F.; Orgill, D.P.; Hamilton, M.J.; Krilis, S.A.; Stevens, R.L. Chapter six-Development of mast cells and importance of their tryptase and chymase serine proteases in inflammation and wound healing. In Advances in Immunology; Alt, F.W., Ed.; Academic Press: Cambridge, MA, USA, 2014; pp. 211-252.

41. Frossi, B.; Mion, F.; Tripodo, C.; Colombo, M.P.; Pucillo, C. Rheostatic functions of mast cells in the control of innate and adaptive immune responses. Trends Immunol. 2017, 38, 648-656. [CrossRef]

42. Galli, S.J.; Nakae, S.; Tsai, M. Mast cells in the development of adaptive immune responses. Nat. Immunol. 2005, 6, 135-142. [CrossRef]

43. John, A.L.S.; Abraham, S.N. Innate immunity and its regulation by mast cells. J. Immunol. 2013, 190, 4458-4463. [CrossRef] [PubMed]

44. Maurer, M.; Wedemeyer, J.; Metz, M.; Piliponsky, A.M.; Weller, K.; Chatterjea, D.; Clouthier, D.E.; Yanagisawa, M.M.; Tsai, M.; Galli, S.J. Mast cells promote homeostasis by limiting endothelin-1-induced toxicity. Nature 2004, 432, 512-516. [CrossRef] [PubMed]

45. Moon, T.C.; Befus, A.D.; Kulka, M. Mast cell mediators: Their differential release and the secretory pathways involved. Front. Immunol. 2014, 5, 569. [CrossRef] [PubMed]

46. Minoda, R.; Toriya, T.; Masuyama, K.; Yumoto, E. The effects of histamine and its antagonists on the cochlear microphonic and the compound action potential of the guinea pig. Auris Nasus Larynx 2001, 28, 219-222. [CrossRef]

47. Azuma, H.; Sawada, S.; Takeuchi, S.; Takeuchi, S.; Kakigi, A.; Takeda, T. Immunohistochemical localization of histamine receptors in rat cochlea. Laryngoscope 2004, 114, 2249-2251. [CrossRef]

48. Takumida, M.; Takumida, H.; Anniko, M. Localization of histamine (H1, H2, H3 and H4) receptors in mouse inner ear. Acta Oto-Laryngol. 2016, 136, 537-544. [CrossRef] 
49. Moller, M.N.; Kirkeby, S.; Vikeså, J.; Nielsen, F.C.; Caye-Thomasen, P. Expression of histamine receptors in the human endolymphatic sac: The molecular rationale for betahistine use in Menieres disease. Eur. Arch. Otorhinolaryngol. 2015, 273, 1705-1710. [CrossRef]

50. Housley, G.D.; Norris, C.H.; Guth, P.S. Histamine and related substances influence neurotransmission in the semicircular canal. Hear Res. 1988, 35, 87-97. [CrossRef]

51. Liu, J.; Fu, T.; Song, F.; Xue, Y.; Xia, C.; Liu, P.; Wang, H.; Zhong, J.; Li, Q.; Chen, J.; et al. Mast cells participate in corneal development in mice. Sci. Rep. 2015, 5, 17569. [CrossRef]

52. Leon, A.; Buriani, A.; Toso, R.D.; Fabris, M.; Romanello, S.; Aloe, L.; Levi-Montalcini, R. Mast cells synthesize, store, and release nerve growth factor. Proc. Natl. Acad. Sci. USA 1994, 91, 3739-3743. [CrossRef]

53. Staecker, H.; Galinovic-Schwartz, V.; Liu, W.; Lefebvre, P.; Kopke, R.D.; Malgrange, B.; Moonen, G.; Van De Water, T.R. The role of the neurotrophins in maturation and maintenance of postnatal auditory innervation. Am. J. Otol. 1996, 17, 486-492.

54. Nautiyal, K.M.; Dailey, C.A.; Jahn, J.L.; Rodriquez, E.; Son, N.H.; Sweedler, J.V.; Silver, R. Serotonin of mast cell origin contributes to hippocampal function. Eur. J. Neurosci. 2012, 36, 2347-2359. [CrossRef] [PubMed]

55. Ribatti, D.; Crivellato, E. The role of mast cell in tissue morphogenesis. Thymus, duodenum, and mammary gland as examples. Exp. Cell Res. 2016, 341, 105-109. [CrossRef] [PubMed]

56. Karasawa, T.; Steyger, P.S. An integrated view of cisplatin-induced nephrotoxicity and ototoxicity. Toxicol. Lett. 2015, 237, 219-227. [CrossRef]

57. Brzezińska-Błaszczyk, E.; Mińcikiewicz, M.; Ochocki, J. Effect of cisplatin and cis-platinum (II) phosphonate complex on murine mast cells. Eur. J. Pharmacol. 1996, 298, 155-158. [CrossRef]

58. Samorapoompichit, P.; Steiner, M.; Lucas, T.; Wachtler, F.; Schedle, A.; Sperr, W.R.; Valent, P. Induction of apoptosis in the human mast cell leukemia cell line HMC-1 by various antineoplastic drugs. Leuk. Lymphoma 2003, 44, 509-515. [CrossRef] [PubMed]

59. Perin, P.; Voigt, F.F.; Bethge, P.; Helmchen, F.; Pizzala, R. iDISCO+ for the study of neuroimmune architecture of the rat auditory brainstem. Front. Neuroanat. 2019, 13, 15. [CrossRef]

(C) 2020 by the authors. Licensee MDPI, Basel, Switzerland. This article is an open access article distributed under the terms and conditions of the Creative Commons Attribution (CC BY) license (http://creativecommons.org/licenses/by/4.0/). 